\title{
Sensitivity of isoprene emissions estimated using MEGAN to the time resolution of input climate data
}

\author{
K. Ashworth, O. Wild, and C. N. Hewitt \\ Lancaster Environment Centre, Lancaster University, LA1 4YQ, Lancaster, UK \\ Received: 2 October 2009 - Published in Atmos. Chem. Phys. Discuss.: 5 November 2009 \\ Revised: 14 January 2010 - Accepted: 25 January 2010 - Published: 3 February 2010
}

\begin{abstract}
We evaluate the effect of varying the temporal resolution of the input climate data on isoprene emission estimates generated by the community emissions model MEGAN (Model of Emissions of Gases and Aerosols from Nature). The estimated total global annual emissions of isoprene is reduced from $766 \mathrm{Tg} \mathrm{y}^{-1}$ when using hourly input data to $746 \mathrm{Tg}^{-1}$ (a reduction of 3\%) for daily average input data and $711 \mathrm{Tg} \mathrm{y}^{-1}$ (down 7\%) for monthly average input data. The impact on a local scale can be more significant with reductions of up to $55 \%$ at some locations when using monthly average data compared with using hourly data. If the daily and monthly average temperature data are used without the imposition of a diurnal cycle the global emissions estimates fall by $27-32 \%$, and local annual emissions by up to $77 \%$. A similar pattern emerges if hourly isoprene fluxes are considered. In order to better simulate and predict isoprene emission rates using MEGAN, we show it is necessary to use temperature and radiation data resolved to one hour. Given the importance of land-atmosphere interactions in the Earth system and the low computational cost of the MEGAN algorithms, we recommend that chemistry-climate models and the new generation of Earth system models input biogenic emissions at the highest temporal resolution possible.
\end{abstract}

\section{Introduction}

Isoprene, $\mathrm{C}_{5} \mathrm{H}_{8}$, is one of a class of chemicals known collectively as volatile organic compounds. It is not only the most abundant of these in the atmosphere, with total annual emissions believed to be equal to that of methane (Guenther

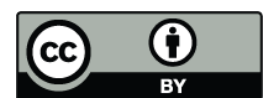

Correspondence to: $\mathrm{K}$. Ashworth (k.ashworth1@lancaster.ac.uk) et al., 1995), but it is also one of the most reactive, with an atmospheric lifetime of around $1.5 \mathrm{~h}$ with respect to the $\mathrm{OH}$ and $\mathrm{NO}_{3}$ radicals (Atkinson and Arey, 2001).

Isoprene emissions are predominantly of biogenic origin (e.g. Guenther et al., 1995; Laothawornkitkul et al., 2009), leading to high mixing ratios of isoprene in the lower troposphere over vegetated land. For example, mixing ratios of isoprene of up to 3.9 ppbv have been observed in the boundary layer above an oil palm plantation in Malaysia (Hewitt et al., 2009). Once released into the boundary layer, isoprene rapidly undergoes a series of photochemically initiated reactions culminating in the production and destruction of tropospheric ozone (Fehsenfeld et al., 1992), a key atmospheric pollutant as well as a long-lived greenhouse gas.

In order to fully understand and predict the occurrence of ground-level ozone, it is necessary to reliably quantify emissions of all volatile organic compounds, and particularly of isoprene (e.g. Chameides et al., 1988), on both global and highly-resolved local scales. Estimates of global and regional isoprene emissions have been generated since the mid1990s (e.g. Guenther et al., 1995; Simpson et al., 1999). Both the algorithms and the input datasets have been improved since then and global emissions are thought to be around $450-600 \mathrm{Tg}^{-1}$. There is still a considerable degree of uncertainty in these figures (Arneth et al., 2008) and work is ongoing to validate these estimates against observations and constrain them using satellite data (e.g. Shim et al., 2005). The next goal is to incorporate these emission models into atmospheric and Earth system models to allow the impact of emissions on atmospheric chemistry and climate to be properly evaluated.

Although research is underway to develop global-scale process-based models of isoprene emissions (e.g. Grote and Niinemets, 2008), the majority of studies into emissions are carried out with the empirical algorithms developed by Guenther et al. (1995), and subsequently refined into

Published by Copernicus Publications on behalf of the European Geosciences Union. 
MEGAN, the Model of Emissions of Gases and Aerosols from Nature (Guenther et al., 2006). The algorithms estimate the flux of isoprene, $\mathrm{F}$, in $\mu \mathrm{g} \mathrm{m}^{-2} \mathrm{~h}^{-1}$, using

$\mathrm{F}=\epsilon \cdot D \cdot \gamma$

where $\epsilon$ is the base emission rate of isoprene from a particular plant species at standard conditions of $30^{\circ} \mathrm{C}$ and $1000 \mu \mathrm{mol} \mathrm{m}^{-2} \mathrm{~s}^{-1}$ of photosynthetically active radiation (PAR), $D$ is the foliar density or leaf area index in $\mathrm{m}^{2} \mathrm{~m}^{-2}$, and $\gamma$ represents a dimensionless activity factor that adjusts the emission rate according to the current growth environment of the plant. $\gamma$ reflects the effect of current and historical temperature and PAR, the leaf age and the soil moisture on isoprene flux. These activity factors and their derivations are fully described by Guenther et al. $(1995,2006)$ so no further details are given here.

Numerous studies have been conducted to evaluate the sensitivity of the MEGAN emissions estimates to variations in, for example, land cover (e.g. Wiedinmyer et al., 2006), climate (e.g., Lathiere et al., 2006; Muller et al., 2008), and leaf area index (e.g. Smiatek and Bogacki, 2005). The most comprehensive analysis was reported in the original MEGAN paper (Guenther et al., 2006) in which total annual global isoprene emissions were computed for different climate and vegetation data sets. This demonstrated that isoprene emissions estimates from the MEGAN model could vary between $500 \mathrm{Tg}^{-1}$ and $750 \mathrm{Tg}^{-1}$ simply due to realistic variations in input data.

To date, none of these studies have addressed the fact that many of the climate data sources have different temporal resolutions. For example, in the MEGAN paper (Guenther et al., 2006), half of the weather datasets used provided 6hourly values of temperature and PAR, while the others gave monthly mean values. While the values were all used to generate hourly data to drive the model, there are inherent assumptions in any method of interpolating between available data points which, given the non-linearity of the response of isoprene emissions to temperature and PAR (e.g. Monson et al., 1992; Guenther et al., 1991, 1993), will have an impact on the results. Indeed, Wang et al. (1998) suggested that their method of interpolating input temperature data resulted in a $20 \%$ increase in total global annual isoprene emissions. In the case of the monthly averaged data there is a loss of extreme values which will affect studies on the impacts of isoprene on climate.

Here, we evaluate the effect that the use of averaged climate data has on estimates of isoprene emissions generated by MEGAN, as well as the impact of altering the time interval at which the model is called within an atmospheric or Earth system model, by using the same climate data for each model run but varying the temporal resolution of that data as supplied to the model.

\section{Method}

The study was conducted using the latest community version of the Model of Emissions of Gases and Aerosols from Nature, MEGAN v2.04, (NCAR 2007). MEGAN v2.04 implements the empirical isoprene emissions algorithms described as the PCEEA approach by Guenther et al. (2006), but neglects the impact of soil moisture and any loss of isoprene in the canopy. This is achieved by setting both of these factors to 1 in MEGAN v2.04.

\subsection{Input data}

The model requires input datasets of vegetation and climate variables. MEGAN v2.04 can be run on any spatial resolution over any geographical domain. For the purposes of this study, the model was run globally on a $0.5^{\circ}$ by $0.5^{\circ}$ regular grid over the course of a year. For each grid cell within the model domain the total flux of isoprene is calculated as the sum of the emissions from each plant functional type (PFT) within that cell.

The vegetation datasets comprise land cover, base emission rates and leaf area index. These input files, as described by Guenther et al. (2006), were all supplied by the National Center for Atmospheric Research (http://cdp.ucar.edu/), thus allowing comparisons to be made between the results of this study and emissions estimates previously generated with the full MEGAN algorithms.

The land cover datafile, version 2.0, gives the distribution of vegetation in terms of the fraction of a grid cell covered by each of the six plant functional types used for isoprene emissions in MEGAN v2.04. The global gridded map of base emission rates of isoprene by plant functional type, version 2.0 , is currently the best resolved data for isoprene, with the emission factors varying with both plant functional type and geographical location. The map gives emission rates at standard conditions of $30^{\circ} \mathrm{C}$ and $1000 \mu \mathrm{mol} \mathrm{m}^{-2} \mathrm{~s}^{-1}$ (NCAR, 2007). NCAR's leaf area index database, version 2.0, contains a gridded map giving the average leaf area per unit vegetated ground area $\left(\mathrm{m}^{2}\right.$ per $\left.1000 \mathrm{~m}^{2}\right)$ for each grid cell for each month of the year (NCAR, 2007).

MEGAN v2.04 also requires input values of the air temperature at $1.5 \mathrm{~m}$ above the surface and the short-wave radiation flux reaching the surface (NCAR, 2007). We used the UK Meteorological Office Unified Model, the UM, as the input climate model as this forms the basis of the UK community Earth system model, QESM. The values of temperature and short-wave radiation were generated by the UM for a year at current climatic conditions following a three month spin up period. UM output is provided at one hour intervals on a $2.5^{\circ}$ by $3.75^{\circ}$ global grid so the data were regridded to a $0.5^{\circ}$ by $0.5^{\circ}$ grid. However, owing to the computational cost of the radiation scheme within the UM, short wave radiation is only sampled every three hours. This has implications for running MEGAN within a fully coupled Earth system model. 
Table 1. Total global annual isoprene emissions, in $\mathrm{Tg}^{-1}$ for each run performed together with full description of input data used. Where daily and monthly average data have been converted to hourly data, this has been done by applying a diurnal cycle. The percentage difference shown is in relation to Run 1, which uses the original UM output temperature and radiation data, and is used as a baseline case.

\begin{tabular}{cllrr}
\hline Run No. & Temperature input data & Radiation input data & Isoprene & \% diff \\
\hline & Hourly input: & & \\
1 & Hourly & 3-hourly $\rightarrow$ hourly by sampling & 766 & 0 \\
2 & Hourly & 3-hourly $\rightarrow$ hourly by interpolation & 773 & +1 \\
3 & Daily $\rightarrow$ hourly & Daily $\rightarrow$ hourly & 746 & -3 \\
4 & Monthly $\rightarrow$ hourly & Monthly $\rightarrow$ hourly & 711 & -7 \\
& 3-hourly input: & & 744 & -3 \\
5 & Hourly $\rightarrow$ 3-hourly by sampling & 3-hourly & 737 & -4 \\
6 & Hourly $\rightarrow$ 3-hourly by averaging & 3 hourly & & \\
& Average temperature input: & & 557 & -27 \\
7 & Daily average & Daily $\rightarrow$ hourly & 536 & -30 \\
8 & Monthly average & Monthly $\rightarrow$ hourly & 741 & -3 \\
& Hourly input sensitivity study: & & 749 & -2 \\
9 & Daily $\rightarrow$ hourly & 3-hourly $\rightarrow$ hourly by sampling & \\
10 & Daily $\rightarrow$ hourly & 3-hourly $\rightarrow$ hourly via interpolation & 770 & 0 \\
11 & Hourly & Daily $\rightarrow$ hourly & 706 & -8 \\
12 & Monthly $\rightarrow$ hourly & 3-hourly $\rightarrow$ hourly by sampling & -7 \\
13 & Monthly $\rightarrow$ hourly & 3-hourly $\rightarrow$ hourly by interpolation & 712 & -3 \\
14 & Hourly & Daily $\rightarrow$ hourly & 740 & \\
& Average temp sensitivity study: & 3-hourly $\rightarrow$ hourly by sampling & 547 & -29 \\
15 & Daily average & 3-hourly $\rightarrow$ hourly by interpolation & 555 & -27 \\
16 & Daily average & 3-hourly $\rightarrow$ hourly by sampling & 524 & -32 \\
17 & Monthly average & 3-hourly $\rightarrow$ hourly by interpolation & 532 & -31 \\
18 & Monthly average & & & \\
& & & & \\
& & &
\end{tabular}

This study is therefore also designed to determine the impact on estimates of isoprene emissions of driving MEGAN at 3hourly, as opposed to hourly, intervals.

The UM output was also used to generate daily and monthly average values of temperature and short-wave radiation, to allow the study to be conducted using exactly the same original data for each run. Hence any differences in results can be entirely attributed to the difference in temporal resolution of the data.

\subsection{Model runs}

The only difference between the model runs is the temporal resolution of the input climate data. The original hourly and 3-hourly data from the UM were combined to drive MEGAN on an hourly time step, in which case the radiation data was converted to provide hourly values either by repeat sampling of the 3-hourly data or by interpolation between successive values, or a 3-hourly time step, in which case the hourly temperature data was either averaged over the time step or sampled at the time of the radiation data.

The daily average temperature and radiation data were converted to hourly data values by imposing a diurnal cycle in the form of a sinusoidal function. In the case of tempera- ture the times for minimum and maximum values were set to 06:00 LT and 14:00 LT respectively with a sine curve fitted between. For the radiation cycle, the local times of dawn and dusk were calculated for each grid cell and a positive sine curve fitted between these time with the radiation set to zero at other times. Full details of the functions used are given in the supplementary material http://www.atmos-chem-phys. net/10/1193/2010/acp-10-1193-2010-supplement.pdf. The MEGAN algorithms were then used at hourly intervals to generate emissions estimates using these values either together or in conjunction with the original temperature or radiation input data as described above. This simple sensitivity analysis allowed us to determine the goodness of fit between the applied diurnal cycle and the original data. The daily average temperature data were also used without the application of a diurnal cycle by repeat sampling of the average value. The monthly average data were used in the same way.

Table 1 shows the combinations of input data for each run performed, together with the global annual total isoprene emissions estimate. In addition hourly (or 3-hourly where appropriate) fluxes were also calculated for each run to allow an evaluation of the effect of varying the temporal resolution of the input data on instantaneous flux estimates that would be required for use with chemistry and climate models 
to simulate changes in air quality and atmospheric composition caused by the emissions of isoprene. The fluxes for each hour were also averaged over a month to generate an "average" $24 \mathrm{~h}$ period for each month to allow comparison with the hourly flux estimates obtained from monthly average input data.

\section{Results}

The estimates of total global annual isoprene emissions are reduced, in some cases markedly, as the temporal resolution of the input data decreases. Table 1 shows the estimates obtained by driving MEGAN at hourly time steps with input climate data with different resolutions. Using daily averaged data with a diurnal cycle applied, Run 3, results in a reduction of around 3\% in the estimate of total global annual emissions; using monthly averaged data, Run 4, decreases the estimate by $7 \%$. Reducing the number of times MEGAN is called over a $24 \mathrm{~h}$ period by switching from an hourly to a 3-hourly time step also reduces the calculated total global annual emissions by about 3-4\%. This has implications for how MEGAN should be used within a coupled Earth system model.

The percentage differences shown in Table 1 are for the total annual global emissions and are thus averaged across the world. Figure 1 shows that on a regional basis, there is large variability in the impact, with the percentage differences for monthly averaged input data, Run 4, ranging from $-55 \%$ in Northern and Eastern Asia to $+5 \%$ along the west coast of South America. It can be seen that while the differences are far smaller if MEGAN is run 3-hourly, Run 5, the largest changes in estimated emissions in this case occur in the tropics where emissions of isoprene are highest.

If a diurnal cycle is not applied to daily or monthly average input data, the calculated flux of isoprene is reduced to such an extent that the results cannot be considered robust. The estimates obtained from this method are given in Table 1, which shows that isoprene emissions are under-estimated by 27-32\% when compared with estimates from hourly data. This represents estimates between 20 and 25\% lower than using averaged data with a diurnal cycle imposed. On a local basis, the reduction is as great as $77 \%$ for the boreal forests of Northern Europe in Runs 17 and 18 which use monthly averaged data.

Instantaneous isoprene fluxes also vary more than the global average percentage differences for each model run shown in Table 1. This variation does not show a consistent pattern in either space or time, and this is illustrated in Figs. 2 and 3, which show the isoprene fluxes estimated for two different locations. Figure 2 shows an area of the Amazon during mid-afternoon local time in January when isoprene emissions are very high. By contrast, Fig. 3 features a region of temperate forest in the northwest USA during early afternoon in July, when the emissions are around a third of
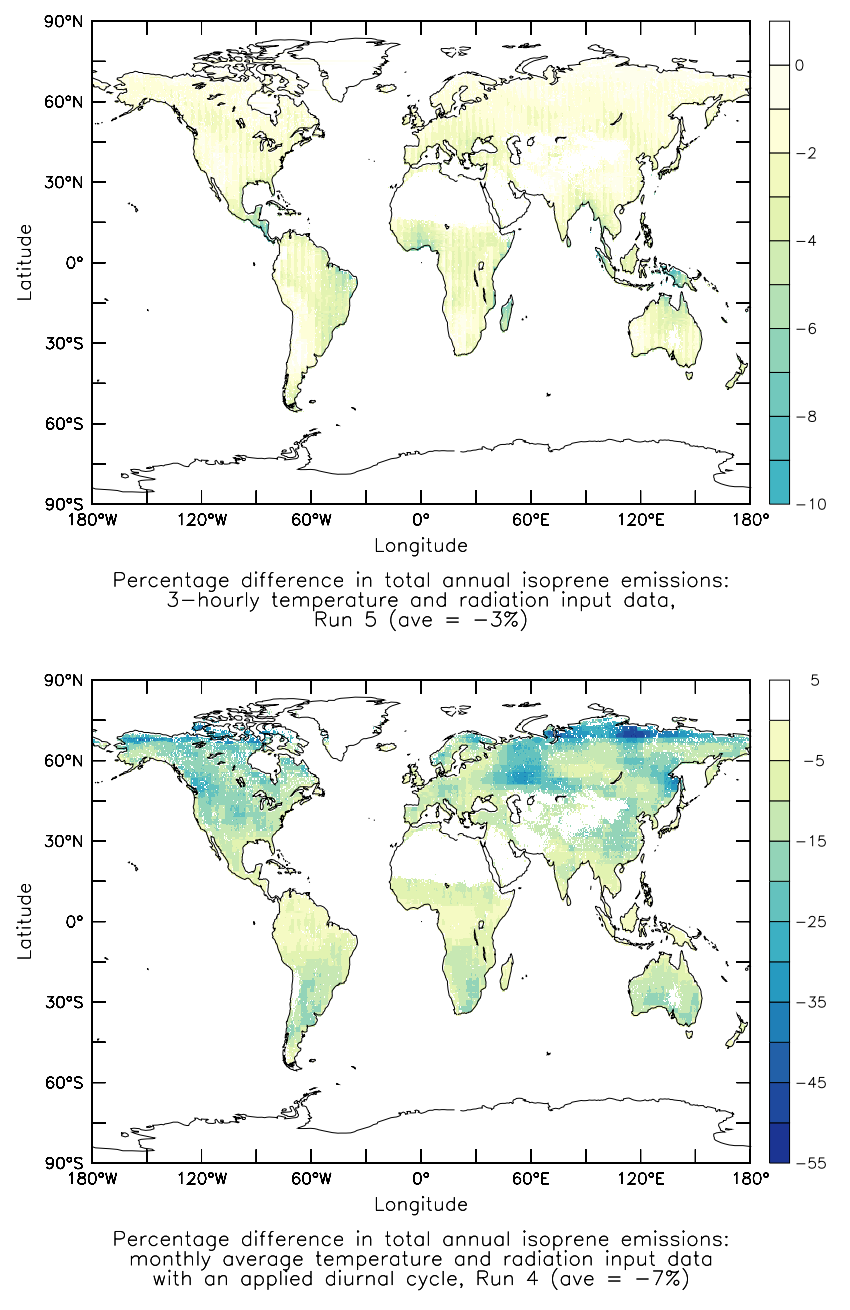

Fig. 1. The percentage difference in global total annual isoprene emissions in comparison with estimates for hourly temperature and repeat sampled radiation for 3-hourly input data (top) and monthly average input data with a diurnal cycle applied (bottom). The figure below each plot indicates the average percentage difference in total global annual isoprene emissions.

those in the Amazon. The figures show the discrepancies between the emissions calculated for that location and time from original hourly data for one day in the middle of January and July respectively, as well as for an average day for each month.

For the Amazon, the 3-hourly emissions show a relatively uniform increase of about $5 \%$ over the hourly emissions. By contrast, using daily average data results in an average percentage decrease of around $20 \%$ with individual grid cells varying between $-10 \%$ and $-40 \%$. The January monthly average emissions for this time of day generated from the original hourly emissions are very close to those shown for 15 January, both in terms of spatial distribution and magnitude, although the average emissions are for the most part slightly lower. The monthly average emissions estimated from monthly average input data are lower still. The average percentage reduction is around $20 \%$ compared with 


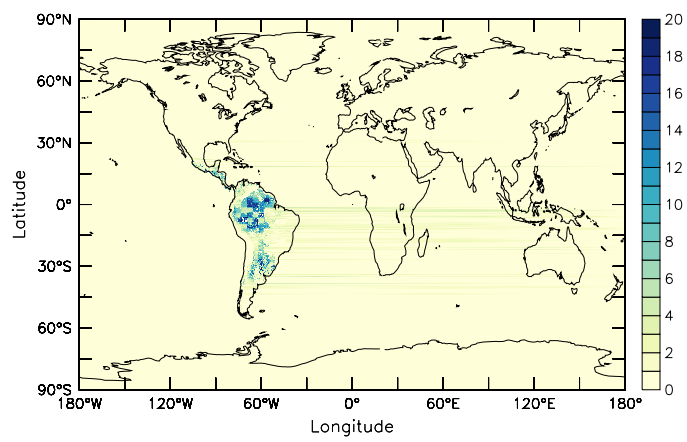

(a) Isoprene emissions $(\mathrm{mg} / \mathrm{m} 2 / \mathrm{h})$ for hourly data (Run 1)
19:30 UTC - Jan 15th

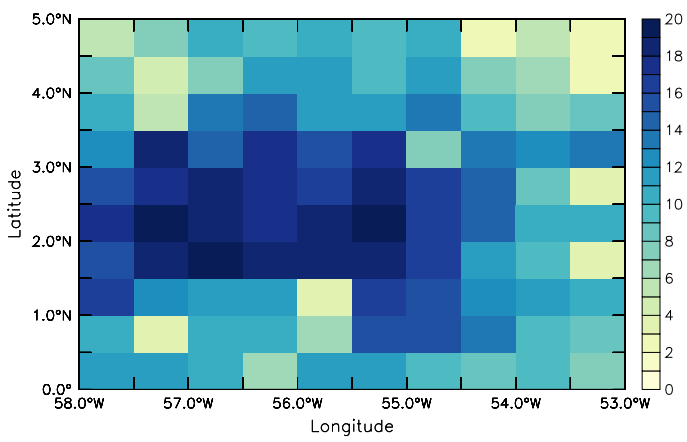

(b) Isoprene emissions ( $\mathrm{mg} / \mathrm{m} 2 / \mathrm{h}$ ) for hourly dato (Run 1)
Amazon - 19:30 UTC - Jan 15th

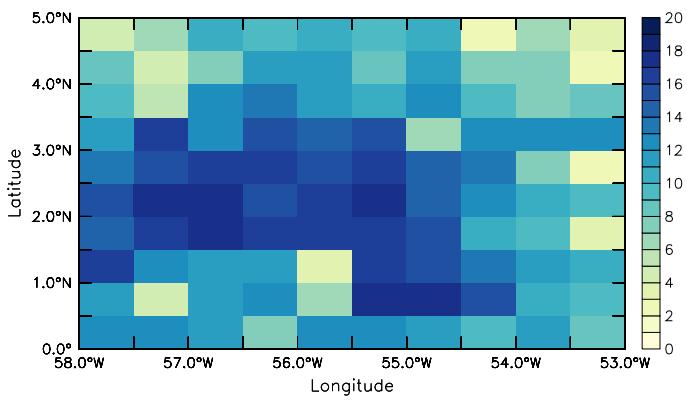

(c) Isoprene emissions $(\mathrm{mg} / \mathrm{m} 2 / \mathrm{h}$ ) for hourly data (Run 1)
Amazon - 19:30 UTC - Average Jan day

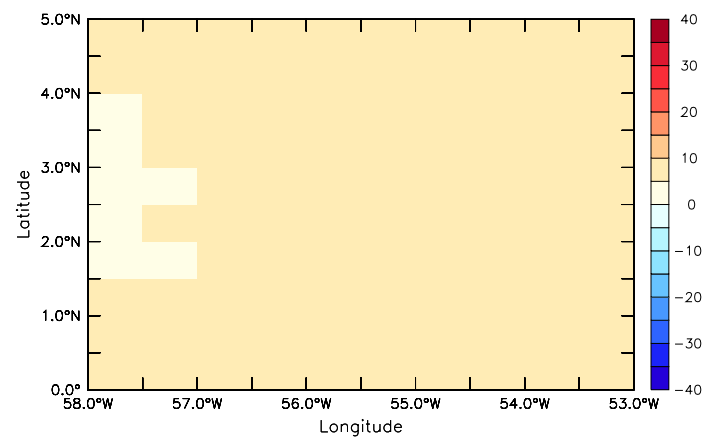

(d) Percentage difference in hourly isoprene emissions Amazon - 19:30 UTC - Jan 15th
3 hourly data (Run 5) cf hourly data (Run 1): ave $=+5.5 \%$

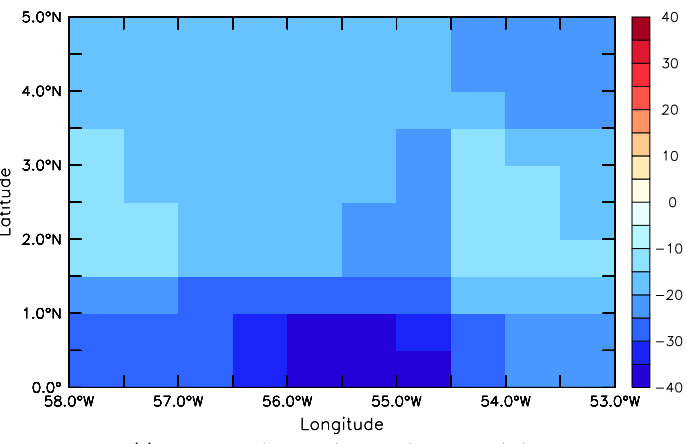

(e) Percentage difference in hourly isoprene emissions daily average data (Run 3) ff hourly dato (Run 1): ave $=-20.3 \%$

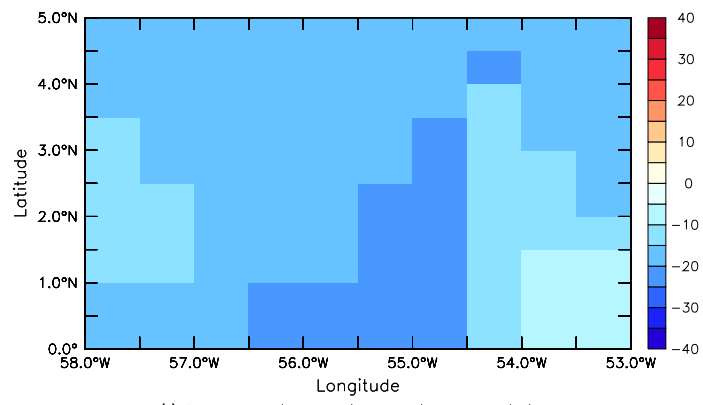

(f) Percentage difference in hourly isoprene emissions
Amazon - 19:30 UTC - Average $\begin{aligned} \text { Amazon } & \text { 19:30 UTC - Average Jan day } \\ \text { monthly average data (Run 4) cf hourly data (Run 1): } & \text { ave }=-18.5 \%\end{aligned}$

Fig. 2. Analysis of the estimated hourly isoprene emissions for a high emitting region of the Amazon (58 to $53 \mathrm{~W}$ and 0 to $5 \mathrm{~N}$ ) at $19: 30 \mathrm{UTC}$ in January. The first column shows the instantaneous fluxes (in $\mathrm{mg} \mathrm{m}^{-2} \mathrm{~h}^{-1}$ ) on 15 January at this time estimated using hourly temperature data and repeat sampled radiation data for (a) the world and (b) the selected region; panel (c) shows regional emissions for an average January day. The second column shows the percentage difference in the instantaneous fluxes for key runs compared with those generated using hourly data. Panels (d) and (e) show differences for the 15 January, for comparison with (b); panel (f) shows differences for an average January day, for comparison with (c). The figure below each panel indicates the average percentage difference for the selected region.

the average day generated from hourly data but the spatial variation is lower than for the daily average data on 15 January. Note that if monthly average emissions are generated from the daily data, the average percentage reduction is only $16.6 \%$, varying between $5 \%$ and $25 \%$.

For the northwest USA 3-hourly emissions show a relatively uniform decrease of about $2.5 \%$. The daily average data suggests little overall difference for this area with an average decrease of less than $2 \%$ compared with the original hourly data. However, this masks significant variations between grid cells with maximum changes of $-30 \%$ and $+10 \%$. The average July day has significantly higher emissions, by a factor of approximately two, than the 15th demon- strating clearly the fluctuations that are missed through the use of monthly average data. Furthermore, the emissions for this representative day are an average of $15 \%$ lower using monthly average data, with individual grid cells showing decreases of between $5 \%$ and $30 \%$. This is due to the nonlinearity of isoprene emissions to changes in temperature and radiation; averaging the input data removes very high and very low emissions in a way that is not reproduced by averaging the emissions calculated from the original data. In this case, the monthly average emissions derived from daily average data show an average increase of $1.5 \%$, varying between $-5 \%$ and $+5 \%$. 


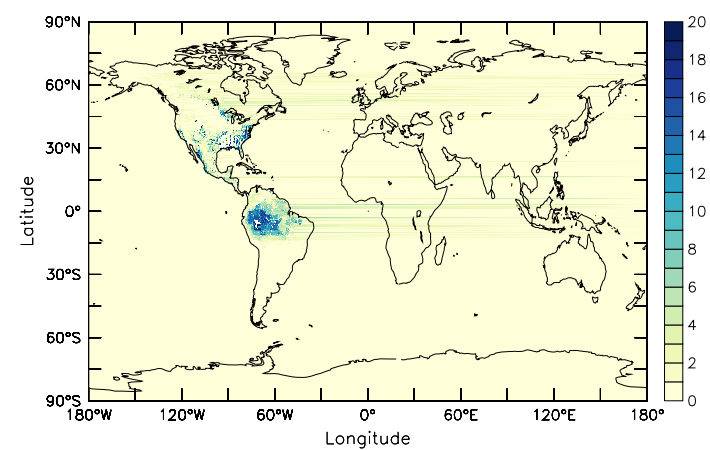

(a) Isoprene emissions $(\mathrm{mg} / \mathrm{m} 2 / \mathrm{h})$ for hourly dato (Run 1)
19:30 UTC - Jul 15th

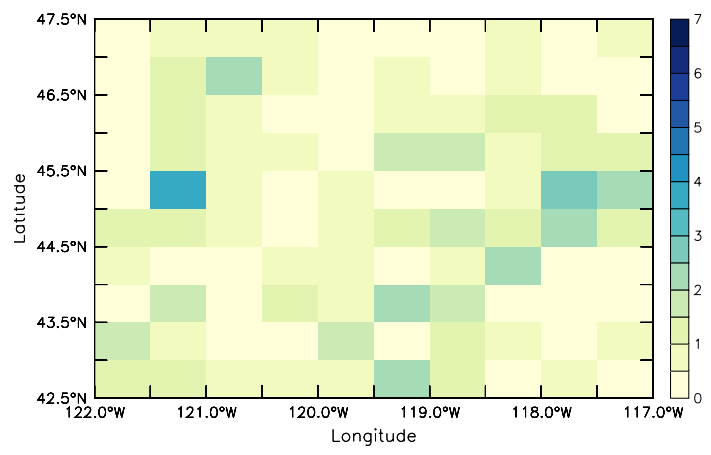

(b) Isoprene emissions ( $\mathrm{mg} / \mathrm{m} 2 / \mathrm{h}$ ) for hourly dato (Run 1)
NW USA - 19:30 UTC - Jul 15th

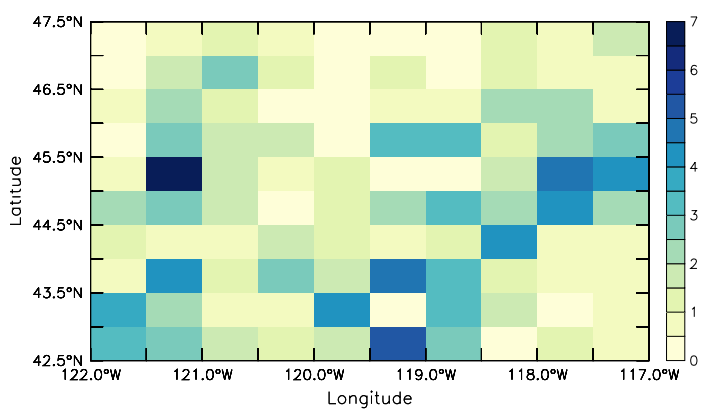

(c) Isoprene emissions ( $\mathrm{mg} / \mathrm{m} 2 / \mathrm{h}$ ) for hourly data (Run 1)
NW USA - 19:30 UTC - Average Jul day

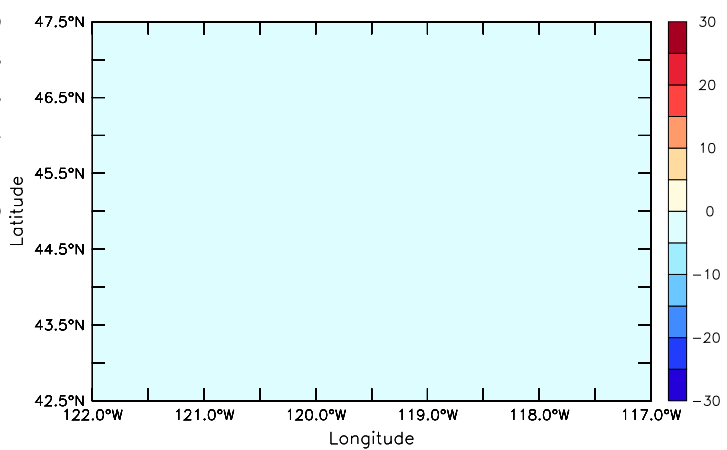

(d) Percentage difference in hourly isoprene emissions

NW USA - 3 hourly data (Run 5) cf hourly data (Run 1): ave $=-2.5 \%$
(Rul 15 th

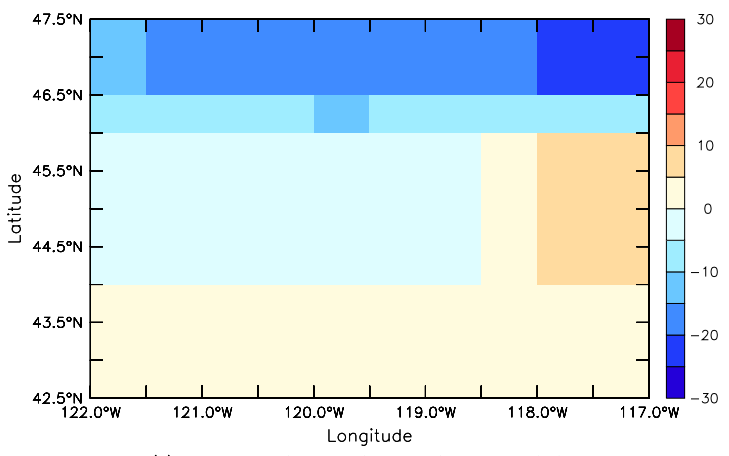

(e) Percentage difference in hourly isoprene emissions
NW USA - 19:30 UTC - Jul 15th

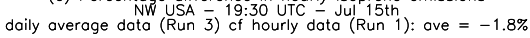

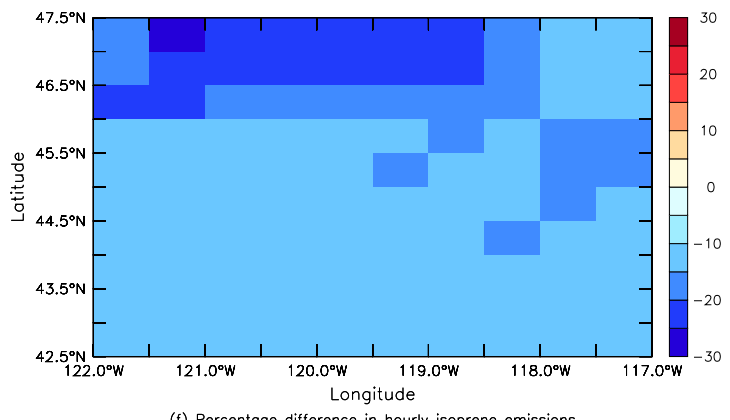

(f) Percentage difference in hourly isoprene emissions
NW USA - $19: 30$ UTC Average Jul doy

Fig. 3. Analysis of the estimated hourly isoprene emissions for a region of the northwest USA ( 122 to $117 \mathrm{~W}$ and 42.5 to $47.5 \mathrm{~N}$ ) at $19: 30 \mathrm{UTC}$ in July. The first column shows the instantaneous fluxes (in mg m $\mathrm{m}^{-2} \mathrm{~h}^{-1}$ ) on 15 July at this time estimated using hourly temperature data and repeat sampled radiation data for (a) the world and (b) the selected region; panel (c) shows regional emisisons for an average July day. The second column shows the percentage difference in the instantaneous fluxes for key runs compared with those generated using hourly data. Panels (d) and (e) show differences for the 15 July, for comparison with (b); panel (f) shows differences for an average July day, for comparison with (c). The figure below each plot indicates the average percentage difference for the selected region.

These two examples illustrate the problems associated with the use of averaged input climate data. The use of daily average data leads to discrepancies in emissions estimates for individual grid cells that may be both high and also highly variable over a small area. While the monthly average results appear more consistent across a given region, it must be remembered that they are an average, and as such miss the day-to-day fluctuations shown clearly in Fig. 3.

The sensitivity studies conducted to assess the effect of using different temperature and radiation input files demonstrate that the diurnal cycle has been effective in capturing the general shape of the original data. Ex- amples of the profiles generated are given in the supplementary material http://www.atmos-chem-phys.net/10/ 1193/2010/acp-10-1193-2010-supplement.pdf. Comparison of Runs 9 and 10 with Run 3 or Run 11 with Run 1 suggests that over the course of a year, the difference in emissions when using global average radiation data is smaller than that using an average temperature profile. However, this global average flux again masks large variations in instantaneous local radiation which is substantially altered by the presence of clouds, a feature that is not reproduced in a simple diurnal profile. In the case of temperature, this issue is further compounded by the process of averaging the original data 
Table 2. The effect of the temporal resolution of the input data on the estimate of total global annual isoprene emissions in $\mathrm{Tg}^{-1}$.

\begin{tabular}{|c|c|c|c|c|}
\hline Study & Input climatology & Isoprene & $\%$ Bias & Adjusted Isoprene \\
\hline Guenther et al. (1995) & Monthly $\rightarrow$ hourly & 570 & -7 & 613 \\
\hline Wang and Shallcross (2000) & ECMWF 6 hourly & 601 & -4 & 626 \\
\hline Potter et al. $(2001)^{\mathrm{a}}$ & Monthly average & 634 & -7 to -32 & 682 to 925 \\
\hline Naik et al. $(2004)^{\mathrm{a}}$ & CRU monthly average & 515 & -7 to -32 & 554 to 752 \\
\hline Tao and Jain $(2005)^{\mathrm{a}}$ & Monthly average & 681 & -7 to -32 & 732 to 994 \\
\hline Lathiere et al. (2006) & ISLSCP-II 3 hourly & 521 & -3 & 537 \\
\hline Muller et al. $(2008)^{\mathrm{b}}$ & ERA 6 hourly $\rightarrow$ hourly & 410 & -3 to 0 & 410 to 423 \\
\hline Guenther et al. (2006) ${ }^{\mathrm{b}}$ & NCEP-DOE $\rightarrow$ hourly & 600 & -3 to 0 & 600 to 619 \\
\hline Guenther et al. (2006) & HadCM1 monthly $\rightarrow$ hourly & 690 & -7 & 742 \\
\hline
\end{tabular}

${ }^{\text {a }}$ It is not clear from this study how the monthly average data were used to drive the emissions algorithms. This is reflected in the ranges given for the bias of the results and the adjusted total emissions.

$\mathrm{b}$ The effect of driving the algorithms with hourly data derived from original 6 hourly data is assumed to lie between using original hourly data and hourly data derived from original daily average data. This is reflected in the ranges given for the bias of the results and the adjusted total emissions.

removing the hour-to-hour, and in the case of monthly averaged data the day-to-day, variability of the temperature and radiation data. Even with the application of a diurnal cycle, this variability is not perfectly reproduced by the diurnal cycle which tends to produce smooth profiles for the data. The temperature cycle appears less accurate because the full $24 \mathrm{~h}$ period must be recreated while emissions only occur during daylight hours. Hence while the average temperature may be maintained, the balance between daytime and night time temperatures may not be. The loss of variability is more pronounced when monthly data is used with emissions reduced by a further $3-4 \%$ in both cases.

For the purposes of atmospheric or Earth system models, the differences between the total global annual emissions estimates obtained from calling MEGAN hourly or 3-hourly with the original UM hourly temperature and 3-hourly radiation data are slight, with total global annual emissions for the interpolated hourly run, Run 2 , only varying by -0.3 to $+2.2 \%$ from the sampled hourly run, Run 1 . The discrepancies in total annual emissions estimates obtained from the 3hourly runs are greater with Run 5 varying by -9.7 to $+1.7 \%$, as shown in Fig. 1, and Run 6 by -10.0 and $+0.7 \%$ in comparison with Run 1. The differences between instantaneous (hourly) fluxes generated by the two hourly runs are negligible for most times of day and location with discrepancies mainly occurring at the start and end of the day when emissions are low. However, as Fig. 2 shows there are more significant differences locally when instantaneous fluxes generated by the 3-hourly runs are considered with Run 5 showing that the fluxes are higher by up to $10 \%$ over part of Amazonia during the early afternoon (LT) when emissions are high. This suggests that MEGAN should be called at every time step of an Earth system model, hourly in the case of QESM, to improve robustness of results.

\section{Conclusions}

Our analysis shows that the previously published estimates for total global annual isoprene emissions, shown in Table 2, obtained from the empirical algorithms described by Guenther et al. $(1995,2006)$ are too low by up to $32 \%$ due to the coarse temporal resolution of the input data that was used. From this we conclude that the highest possible temporal resolution of input climate data should be used when calculating isoprene emissions using the MEGAN model. If hourly data are not available, for example when performing studies of historical emissions or to investigate future scenarios when the emissions are to be used in conjunction with datasets of anthropogenic emissions (Lamarque et al., 2009), then total global annual emissions estimates should be adjusted to an hourly result to ensure comparability between studies. Table 2 shows the effect of such an adjustment on the estimates from previous studies. It suggests that the impact of factors such as land cover, climate and land use change may be more significant than previously thought, as the range of emissions increases markedly.

Our results clearly indicate that daily or monthly averaged climate data should not be used without the imposition of a diurnal cycle, even if the purpose of the study is to generate daily or monthly average emissions estimates. We have found that the results obtained in this way do not give reliable estimates of isoprene emissions with an overall global underestimate of $25-30 \%$ and results locally varying between an increase of $5 \%$ and a decrease of $77 \%$.

For local and regional studies in particular, data of a high temporal resolution should be used as our study shows that local discrepancies in isoprene flux are much higher than the overall percentage differences on a global scale. These differences are more pronounced the coarser the resolution of 
the original data, even with the imposition of a diurnal cycle onto averaged data. For example, using hourly data regenerated from daily averaged data under-estimates total global annual isoprene emissions by $3 \%$, but on a local basis the discrepancies range from $15 \%$ under-estimate to $9 \%$ overestimate when compared with the original data. The fluctuations in hourly fluxes are even more pronounced with an under-estimate of $40 \%$ for one region of Amazonia for early afternoon (LT) in mid-January.

For the purposes of atmospheric and Earth system modelling, these large differences in both instantaneous and total fluxes on a local scale may have a significant impact on both chemistry and climate. Given the low computational cost of the MEGAN algorithms, together with non-linearity of chemistry and climate responses to changes in isoprene fluxes, we recommend that MEGAN is called as often as is computationally feasible within an atmospheric or Earth system model, and ideally at a climate time step of not more than one hour.

Acknowledgements. This work was funded by a NERC studentship to KA and through the QUEST-QUAAC project, NERC grant number NE/C001621/1. We thank Alex Guenther and Christine Wiedinmyer for their discussions and assistance with MEGAN.

Edited by: J. Rinne

\section{References}

Arneth, A., Monson, R. K., Schurgers, G., Niinemets, Ü., and Palmer, P. I.: Why are estimates of global terrestrial isoprene emissions so similar (and why is this not so for monoterpenes)?, Atmos. Chem. Phys., 8, 4605-4620, 2008,

http://www.atmos-chem-phys.net/8/4605/2008/.

Atkinson, R. and Arey, J.: Gas-phase tropospheric chemistry of biogenic volatile organic compounds: a review, in: 1997 Southern California Ozone Study (SCOS97-NARSTO) Data Analysis Conference, Los Angeles, California, suppl., 37(2), S197-S219, 2001.

Chameides, W. L., Lindsay, R. W., Richardson, J., and Kiang, C. S.: The role of biogenic hydrocarbons in urban photochemical smog - Atlanta as a case-study, Science, 241, 1473-1475, 1988.

Fehsenfeld, F., Calvert, J., Fall, R., Goldan, P., Guenther, A., Hewitt, C. N., Lamb, B., Liu, S., Trainer, M., Westberg, H., and Zimmerman, P.: Emissions of volatile organic compounds from vegetation and their implications for atmospheric chemistry, Global Biogeochem. Cy., 6, 389-430, 1992.

Grote, R. and Niinemets, U.: Modeling volatile isoprenoid emissions - a story with split ends, Plant Biol., 10, 8-28, 2008.

Guenther, A., Hewitt, C. N., Erickson, D., Fall, R., Geron, C., Graedel, T., Harley, P., Klinger, L., Lerdau, M., McKay, W. A., Pierce, T., Scholes, B., Steinbrecher, R., Tallamraju, R., Taylor, J., and Zimmerman, P.: A global-model of natural volatile organic-compound emissions, J. Geophys. Res.-Atmos., 100, 8873-8892, 1995.

Guenther, A., Karl, T., Harley, P., Wiedinmyer, C., Palmer, P. I., and Geron, C.: Estimates of global terrestrial isoprene emissions using MEGAN (Model of Emissions of Gases and Aerosols from Nature), Atmos. Chem. Phys., 6, 3181-3210, 2006,

http://www.atmos-chem-phys.net/6/3181/2006/.

Guenther, A. B., Monson, R. K., and Fall, R.: Isoprene and monoterpene emission rate variability - observations with eucalyptus and emission rate algorithm development, J. Geophys. Res.-Atmos., 96, 10799-10808, 1991.

Guenther, A. B., Zimmerman, P. R., Harley, P. C., Monson, R. K., and Fall, R.: Isoprene and monoterpene emission rate variability - model evaluations and sensitivity analyses, J. Geophys. Res.Atmos., 98, 12609-12617, 1993.

Hewitt, C. N., MacKenzie, A. R., Di Carlo, P., Di Marco, C. F., Dorsey, J. R., Evans, M., Fowler, D., Gallagher, M. W., Hopkins, J. R., Jones, C. E., Langford, B., Lee, J. D., Lewis, A. C., Lim, S. F., McQuaid, J., Misztal, P., Moller, S. J., Monks, P. S., Nemitz, E., Oram, D. E., Owen, S. M., Phillips, G. J., Pugh, T. A. M., Pyle, J. A., Reeves, C. E., Ryder, J., Siong, J., Skiba, U., and Stewart, D. J.: Nitrogen management is essential to prevent tropical oil palm plantations from causing ground-level ozone pollution, Proc. Natl. Acad. Sci. USA, 106, 44, 18447-18451, 2009.

Lamarque, J., Granier, C., Bond, T., Eyring, V., Heil, A., Kainuma, M., Lee, D., Liousse, C., Mieville, A., Riahi, K., Schultz, M., Smith, S., Stehfast, E., Stevenson, D., Thomson, A., van Aardenne, J., and van Vuuren, D.: Gridded emissions in support of IPCC AR5, IGACtivities Newsletter, 41, 12-18, May 2009.

Laothawornkitkul, J., Taylor, J. E., Paul, N. D., and Hewitt, C. N.: Biogenic volatile organic compounds in the Earth system, New Phytol., 183, 27-51, 2009.

Lathière, J., Hauglustaine, D. A., Friend, A. D., De NobletDucoudré, N., Viovy, N., and Folberth, G. A.: Impact of climate variability and land use changes on global biogenic volatile organic compound emissions, Atmos. Chem. Phys., 6, 2129-2146, 2006, http://www.atmos-chem-phys.net/6/2129/2006/.

Monson, R. K., Jaeger, C. H., Adams, W. W., Driggers, E. M., Silver, G. M., and Fall, R.: Relationships among isoprene emission rate, photosynthesis, and isoprene synthase activity as influenced by temperature, Plant Physiol., 98, 1175-1180, 1992.

Müller, J.-F., Stavrakou, T., Wallens, S., De Smedt, I., Van Roozendael, M., Potosnak, M. J., Rinne, J., Munger, B., Goldstein, A., and Guenther, A. B.: Global isoprene emissions estimated using MEGAN, ECMWF analyses and a detailed canopy environment model, Atmos. Chem. Phys., 8, 1329-1341, 2008, http://www.atmos-chem-phys.net/8/1329/2008/.

Naik, V., Delire, C., and Wuebbles, D. J.: Sensitivity of global biogenic isoprenoid emissions to climate variability and atmospheric $\mathrm{CO}_{2}$, J. Geophys. Res.-Atmos., 109, D06301, doi:10.1029/2003JD004236, 2004.

NCAR: Operating instructions for the MEGAN model, National Center for Atmospheric Research, http://cdp.ucar.edu/, last access: January 2009, 2007.

Potter, C. S., Alexander, S. E., Coughlan, J. C., and Klooster, S. A.: Modeling biogenic emissions of isoprene: exploration of model drivers, climate control algorithms, and use of global satellite observations, Atmos. Environ., 35, 6151-6165, 2001.

Shim, C., Wang, Y. H., Choi, Y., Palmer, P. I., Abbot, D. S., and Chance, K.: Constraining global isoprene emissions with Global Ozone Monitoring Experiment (GOME) formaldehyde column measurements, J. Geophys. Res.-Atmos., 110, D24301, 
doi:10.1029/2004JD005629, 2005.

Simpson, D., Winiwarter, W., Borjesson, G., Cinderby, S., Ferreiro, A., Guenther, A., Hewitt, C. N., Janson, R., Khalil, M. A. K., Owen, S., Pierce, T. E., Puxbaum, H., Shearer, M., Skiba, U., Steinbrecher, R., Tarrason, L., and Oquist, M. G.: Inventorying emissions from nature in Europe, J. Geophys. Res.-Atmos., 104, 8113-8152, 1999.

Smiatek, G. and Bogacki, M.: Uncertainty assessment of potential biogenic volatile organic compound emissions from forests with the Monte Carlo method: Case study for an episode from 1 to 10 July 2000 in Poland, J. Geophys. Res.-Atmos., 110, D23304, doi:10.1029/2004JD005685, 2005.

Tao, Z. N. and Jain, A. K.: Modeling of global biogenic emissions for key indirect greenhouse gases and their response to atmospheric $\mathrm{CO}_{2}$ increases and changes in land cover and climate, J. Geophys. Res.-Atmos., 110, D21309, doi:10.1029/2005JD005874, 2005.
Wang, K. Y. and Shallcross, D. E.: Modelling terrestrial biogenic isoprene fluxes and their potential impact on global chemical species using a coupled LSM-CTM model, Atmos. Environ., 34, 2909-2925, 2000.

Wang, Y. H., Jacob, D. J., and Logan, J. A.: Global simulation of tropospheric $\mathrm{O}_{3}-\mathrm{NO}_{\mathrm{x}}$-hydrocarbon chemistry 1. Model formulation, J. Geophys. Res.-Atmos., 103, 10713-10725, 1998.

Wiedinmyer, C., Tie, X. X., Guenther, A., Neilson, R., and Granier, C.: Future changes in biogenic isoprene emissions: How might they affect regional and global atmospheric chemistry, Earth Interact., 10, EI174, doi:10.1175/EI174.1, 2006. 